Available online at http://journal.stkip-andi-matappa.ac.id/index.php/histogram/index

Histogram: Jurnal Pendidikan Matematika 4(2)., 2020, 342 - 354

\title{
MODEL PJBL DENGAN LEMBAR KWL DALAM MENINGKATKAN KEMAMPUAN BERPIKIR KREATIF MATEMATIS
}

\author{
Astri May Handayani ${ }^{1}$, Uki Suhendar ${ }^{2}$, Senja Putri Merona ${ }^{3}$ \\ 123 Universitas Muhammadiyah Ponorogo \\ *Corresponding Author, Email : astrimay18@gmail.com \\ Received: 11 Juni 2020: Revised: 15 September 2020 ; Accepted: 30 September 2020
}

\begin{abstract}
ABSTRAK
Berpikir kreatif adalah kemampuan seseorang yang perlu dikembangkan di sekolah dan diharapkan guru dapat merealisasikan pembelajaran yang membuat kemampuan berpikir kreatif itu dapat berkembang. Kombinasi dari model PjBL dengan lembar kerja KWL dilakukan sebagai upaya agar kemampuan berpikir kreatif matematis semakin meningkat. Penelitian ini memiliki tujuan yaitu mendeskripsikan model PjBL yang dikombinasikan dengan lembar kerja KWL dalam meningkatkan atau mempengaruhi kemampuan berpikir kreatif matematis peserta didik. Metode yang digunakan untuk penelitian ini berbentuk kajian literatur dengan cara mengumpulkan bahan tulisan dari artikel-artikel pada jurnal dan buku-buku yang membahas tentang model PjBL dan KWL. Dari penelitian ini diperoleh hasil bahwa terdapat perbedaan kemampuan berpikir kreatif matematis peserta didik yang dikenai model PjBL dengan lembar kerja KWL dengan yang dikenai model pembelajaran secara langsung dan kemampuan berpikir kreatif matematis dapat ditingkatkan dengan kombinasi dari model PjBL dengan lembar kerja KWL. Dengan tahapantahapan dari model PjBL yang dikombinasikan dengan lembar kerja KWL ini, dapat menjadikan peserta didik lebih mengerti dengan materi yang telah dipelajari melalui proses-proses penyelesaian masalah matematika dengan pembuatan proyek ataupun karya nyata sehingga meningkatkan kreativitas peserta didik. Penggunaan lembar kerja KWL dapat mengontrol kegiatan pembelajaran menjadi lebih efisien dan sistematis serta dapat mengatasi masalah penggunaan waktu pada model PjBL supaya lebih fokus dalam kegiatan pembelajaran.
\end{abstract}

Kata Kunci : PjBL, lembar kerja KWL, kemampuan berpikir kreatif

\section{ABSTRACT}

Creative thinking is a person's ability that needs to be developed in school and it's hoped that the teacher can realize learning that makes creative thinking skills can be developed. The combination of the PjBL model with the KWL worksheet is done as needed. This study has the goal of describing the PjBL model combined with the KWL worksheet in improving or enhancing student's creative thinking skills. The method used for this study examines the literature by collecting written material from articles in journals and books that discuss the PjBL model and KWL. From this study the results obtained from research that produce mathematical creative students who are subjected to the PjBL model with the KWL worksheet with those who are subjected to the PjBL model with the KWL worksheet with those who are subjected to learning models of mathematical creative thinking ability that can be supported by a combination of the PjBL model with the contents of the KWL worksheet. With the stages of the PjBL model combined with this KWL worksheet, students can better understand the material learned through mathematical problem-solving processes by making projects through real work increasing student motivation. The use of the KWL worksheet can organize learning activities more efficiently and systematically and can overcome the problem of using time on the PjBL model so that it's more focused on learning activities.

Keywords: PjBL, KWL worksheet. creative thinking ability

How to Cite: Handayani, A, M., Suhendar, U., \& Merona, S, P. (2020). Model PJBL Dengan Lembar KWL Dalam Meningkatkan Kemampuan Berpikir Kreatif Matematis. Histogram: Jurnal Pendidikan Matematika, 4(2), 342 - 354, doi: http://dx.doi.org/10.31100/histogram.v4i2.647

Permalink/DOI: http://dx.doi.org/10.31100/histogram.v4i2.647 


\section{Histogram: Jurnal Pendidikan Matematika, 4 (2), 2020 - 343 \\ Astri May Handayani', Uki Suhendar², Senja Putri Merona ${ }^{3}$}

\section{PENDAHULUAN}

Pendidikan pada abad ke-21 akan mengusung paradigma pembelajaran yang menuntut lulusannya nanti memiliki keterampilan berpikir tingkat tinggi yang logis, kreatif, kritis, dan inovatif. Dengan kondisi tersebut, untuk perkembangan ilmu pengetahuan dan teknologi pada pendidikan di Indonesia sangat membutuhkan tenagatenaga kreatif untuk memberikan sumbangan yang bermakna. oleh karena itu, penyelenggaraan pendidikan kelak akan mampu memenuhi kebutuhan bangsa dan Negara sehingga mereka dapat berkembang.

Berpikir kreatif adalah kemampuan seseorang yang perlu dikembangkan di sekolah dan diharapkan guru dapat merealisasikan pembelajaran yang membuat kemampuan berpikir kreatif itu dapat berkembang. Kemampuan tersebut dapat dilihat pada prestasi yang diperoleh dalam pembelajaran. dalam belajar matematika peserta didik biasanya menggunakan keterampilan dasar, namun dalam pemikiran tingkat tinggi seharusnya juga perlu dilakukan inovasi yang berbeda karena ini akan menjadikan tantangan belajar matematika bagi peserta didik.

Berdasarkan pertimbangan agar mendukung pembelajaran di sekolah, kemampuan berpikir kreatif matematis perlu ditingkatkan dan untuk itu dapat digunakan model pembelajaran. Menurut Yam dan Rossini (Yam \& Rossini, 2010) Model Project Based Learning (PjBL) dapat diartikan sebagai pendekatan yang berpotensi mengubah kegiatan pasif dengan dukungan alat dan media yang memungkinkan hasil belajar peserta didik semakin meningkat. Sehingga model PjBL digunakan untuk membuat perencanaan, komunikasi, penyelesaian masalah, dan membuat keputusan dari masalah yang dihadapi agar kemampuan berpikir kreatif matematis dapat berkembang. Hal ini dapat menyebabkan pemikiran kreatif dan inovatif peserta didik semakin meningkat yang dapat mengarah dalam memperoleh sebuah jawaban alternatif yang berbeda dengan sebelumnya. Penggunaan waktu yang cukup lama merupakan salah satu permasalahan yang harus dihadapi saat menggunakan model PjBL.

Know Want Learn (KWL) merupakan sebuah kerangka kerja yang digunakan untuk menghubungkan pengetahuan awal peserta didik melalui pembelajaran yang aktif (Ogle, 1986). Oleh karena itu, lembar kerja KWL dapat digunakan sebagai pengontrol kegiatan agar lebih efisien dan sistematis dalam penggunaan waktu supaya lebih fokus pada pekerjaan peserta didik. Strategi KWL ini cukup sederhana dan jelas, serta memiliki dampak yang signifikan apabila diterapkan dalam pembelajaran. Hal ini dapat diketahui berdasarkan hasil penelitian terdahulu bahwa dengan KWL pembelajaran akan lebih 


\section{Histogram: Jurnal Pendidikan Matematika, 4 (2), 2020 - 344 \\ Astri May Handayani', Uki Suhendar², Senja Putri Merona ${ }^{3}$}

efektif dan efisien serta tepat waktu sesuai yang direncanakan. Penggunaan lembar kerja KWL ini akan dikombinasikan dengan tahapan-tahapan pada model PjBL. Kombinasi dari model PjBL dengan lembar kerja KWL diharapkan dapat mengatasi masalah penggunaan waktu pada model PjBL dan kemampuan berpikir kreatif matematis dapat ditingkatkan.

Penelitian ini difokuskan untuk mendeskripsikan model PjBL yang dikombinasikan dengan lembar kerja KWL sehingga dapat meningkatkan atau mempengaruhi kemampuan berpikir kreatif matematis. Kombinasi dari model ini dengan lembar kerja tersebut diharapkan mampu meningkatkan kreativitas peserta didik. Kombinasi tersebut akan memberikan suasana belajar di kelas menjadi lebih bervariasi, sehingga peserta didik dapat lebih bebas dan aktif dalam berkomunikasi serta dalam proses pembelajaran dapat berpikir kreatif dan pengalaman baru akan ditemukan.

\section{METODE PENELITIAN}

Metode penelitian yang akan digunakan adalah deskriptif kualitatif berbentuk kajian literatur. Metodologi penelitiannya adalah dengan pengumpulan bahan tulisan dari artikel-artikel pada jurnal dan buku-buku yang membahas tentang model PjBL dan KWL.

\section{HASIL DAN PEMBAHASAN}

\section{A. Hasil Penelitian}

1. Penelitian yang Relevan

(Maula, dkk., 2014) menyatakan bahwa ada perbedaan hasil belajar siswa dari perlakuan dengan menggunakan model $\mathrm{PjBL}$ terhadap kemampuan berpikir kreatif dibandingkan dengan perlakuan menggunakan model konvensional pada materi pengelolaan lingkungan kelas VII SMP Negeri 2 Balungan Jember Penelitian selanjutnya adalah penelitian oleh Hesti Noviyana (Noviyana, 2017) di kelas VIII A semester genap SMPN 3 Bandar Lampung yang menunjukkan bahwa terdapat pengaruh pada model Project Based Learning terhadap kemampuan berpikir kreatif matematika siswa

(Utami, dkk., 2015) menunjukkan bahwa model pembelajaran PjBL berbantu Instagram berpengaruh terhadap kemampuan berpikir kreatif siswa kelas X SMAN 8 Surakarta. Selanjutnya (Fitrina, dkk., 2016) melakukan penelitian tentang peningkatan kemampuan berpikir kreatif dan komunikasi matematis siswa SMA melalui model pembelajaran Project Based Learning berbasis debat dan ditunjukkan bahwa kemampuan berpikir kreatif matematis siswa yang mendapatkan pembelajaran dengan model pembelajaran PBL peningkatannnya lebih baik dibandingkan dengan kemampuan 


\section{Histogram: Jurnal Pendidikan Matematika, 4 (2), 2020 - 345 \\ Astri May Handayani', Uki Suhendar², Senja Putri Merona ${ }^{3}$}

berpikir kreatif matematis siswa yang mendapatkan pembelajaran konvensional ditinjau dari seluruh siswa.

Satria Mihardi, Mara Bangun Harahap, Ridwan Abdullah Sani (Mihardi, dkk., 2013) juga melakukan penelitian tentang pengaruh model PjBL dengan lembar kerja KWL terhadap kemampuan berpikir kreatif siswa pada permasalahan fisika. Dari penelitian tersebut menunjukkan hasil bahwa terdapat perbedaan antara model $\mathrm{PjBL}$ dengan lembar kerja KWL dan pembelajaran berbasis proyek terhadap kemampuan berpikir kreatif siswa. Sehingga model PjBL dengan lembar kerja KWL ini mempengaruhi kemampuan berpikir kreatif siswa dalam memecahkan masalah pada bidang fisika.

2. Perbedaan Peserta Didik yang Dikenai Model PjBL dengan Lembar Kerja KWL dan Peserta Didik yang Dikenai Model Pembelajaran Langsung dalam Peningkatan Kemampuan Berpikir Kreatif Matematis

Berdasarkan beberapa kajian literatur tersebut, ada perbedaan antara peserta didik yang dikenai model PjBL dengan lembar kerja KWL dengan yang dikenai model pembelajaran langsung dalam meningkatkan kemampuan berpikir kreatif matematis. Perbedaan ini dikarenakan kombinasi model PjBl dengan lembar kerja KWL lebih menekankan pembelajaran yang berkaitan dengan pembuatan proyek tertentu. Selain itu, kombinasi dari model PjBL dengan lembar kerja KWL dapat mengatasi masalah penggunaan waktu pada model PjBL sehingga pembelajaran menjadi lebih efisien dan sistematis. Pembelajaran yang berkaitan dengan pembuatan proyek inilah dapat membuat peserta didik lebih paham dengan konsep-konsep materi yang diberikan dan kreativitasnya akan meningkat. Dengan pemahaman materi yang baik tentu dampaknya akan baik pula pada hasil belajar yang diterima peserta didik. Sedangkan untuk model pembelajaran langsung, kegiatan pembelajaran akan lebih terpaku pada guru. Hal ini dapat menjadikan peserta didik pasif saat di kelas dan hanya dapat menerima dan mengingat apa yang sudah dipelajari serta cenderung menghafal konsep yang dijelaskan guru. Akibatnya peserta didik hanya mampu menjawab pertanyaan dengan menggunakan rumus yang telah tersedia tanpa memahaminya lebih dalam.

\section{B. Pembahasan}

1. Kemampuan Berpikir Kreatif

Hasanah dan Surya (Widiana \& Hernadi, 2018) mengatakan berpikir kreatif matematika merupakan kemampuan seseorang dalam penemuan solusi yang berbedabeda dari suatu masalah matematika dengan mengetahui kualitas dari jawabannya. 


\section{Histogram: Jurnal Pendidikan Matematika, 4 (2), 2020 - 346 Astri May Handayani', Uki Suhendar², Senja Putri Merona ${ }^{3}$}

Sehingga menjadikan berpikir kreatif sebagai salah satu syarat agar peserta didik menjadi aktif. Menurut Noviyana (Noviyana, 2017) kemampuan berpikir kreatif dapat didefinisikan sebagai kemampuan dengan hasil berupa gagasan atau ide-ide atau karya nyata dan berbeda dengan sebelumnya. Selanjutnya kemampuan berpikir kreatif didefinisikan sebagai kemampuan seseorang untuk memperoleh jawaban dari suatu permasalahan menantang berdasarkan ide maupun gagasan dan hasilnya dapat berupa produk (Aminullah, 2017).

Kemampuan berpikir kreatif peserta didik adalah kemampuan seseorang dalam memperoleh kemungkinan banyak jawaban operasional berdasarkan informasi dan data yang didapatkan (Sulistiarmi, 2016). Selain itu, menurut Moma (Moma, 2015) berpikir kreatif merupakan aktivitas mental dalam memperoleh solusi dari suatu masalah yang ada kaitannya dengan kepekaan, ide-ide, dan informasi terbaru yang perlu dipertimbangkan dan pemikiran seseorang menjadi terbuka.

Berdasarkan pendapat tersebut, kemampuan berpikir kreatif matematis didefinisikan sebagai kemampuan yang dimiliki seseorang dalam menemukan ide atau gagasan baru untuk mencari solusi dari permasalahan matematika dengan penalaran deduktif yang logis dan divergen. Selain itu, dari kemampuan tersebut dapat dihasilkan suatu gagasan maupun karya nyata berupa produk yang belum ada sebelumnya.

Kemampuan berpikir kreatif menurut Munandar (Fitriarosah, 2016) memiliki ciri-ciri sebagai berikut : (1) Berpikir Dengan Lancar (Fluency): Berpikir dengan lancar yaitu kemampuan dalam memperoleh banyak jawaban, pendapat, memberikan banyak saran maupun cara untuk beberapa hal dan meninjau jawaban lain; (2) Berpikir Dengan Luwes (Flexibility): Berpikir dengan luwes yaitu kemampuan dalam mengutarakan banyak jawaban, gagasan, ataupun pernyataan bervariasi, mampu mengetahui solusi dari pandangan yang berbeda dan dapat memperbaiki strategi dalam mendapatkan solusi dari suatu permasalahan; (3) Berpikir Orisinil (Originality): Berpikir orisinil yaitu kemampuan dalam menciptakan gagasan terbaru yang inovatif, meninjau cara yang tidak wajar untuk mengekspresikan dirinya, dan dapat melahirkan kolaborasi yang tidak wajar; (4) Berpikir Secara Terperinci (Elaboration): Berpikir secara terperinci yaitu kemampuan dalam mengembangkan, mengeluarkan sebuah ide ataupun gagasan maupun produk dan memerinci secara keseluruhan dari situasi supaya lebih menarik.

Berdasarkan indikator tersebut, kemampuan berpikir kreatif matematis dapat ditingkatkan dengan membiasakan peserta didik menemukan banyak cara atau penyelesaian dari suatu masalah, menghasilkan gagasan yang bervariasi, melahirkan 


\section{Histogram: Jurnal Pendidikan Matematika, 4 (2), 2020 - 347 Astri May Handayani', Uki Suhendar², Senja Putri Merona ${ }^{3}$}

gagasan baru yang unik, dab mengembangkan sebuah ide secara detail sehingga lebih menarik.

\section{Project Based Learning}

Project Based Learning (PjBL) dapat diartikan sebagai model pembelajaran inovatif yang pusatnya adalah peserta didik (student centered), yang dimana peserta didik diberikan peluang untuk berkerja dengan bebas saat mengonstruksi belajar dalam pemecahan masalah, mengambil keputusan, meneliti, mempresentasikan melalui kerja proyek, dan menghasilkan proyek karya peserta didik bernilai realistik, dan guru ditempatkan sebagai fasilitator dan motivator (Aminullah, 2017). Menurut Thomas (Gülbahar \& Tinmaz, 2006) Project Based Learning dapat didefinisikan sebagai model yang mengatur pembelajaran melalui proyek tertentu. Proyek yang dimaksudkan disini adalah tugas yang diberikan oleh guru dan berupa masalah menantang, keterlibatan peserta didik dalam merancang, menyelesaikan masalah, menyelidiki aktivitas atau memberikan keputusan, memberikan hak pada peserta didik secara bebas selama periode waktu tertertu, puncaknya adalah hasil proyek atau presentasi yang nyata.

Menurut (Sani, 2015) Project Based Learning adalah suatu model pembelajaran yang berguna untuk memecahkan masalah dalam kehidupan nyata dalam aktivitas jangka panjang dengan keterlibatan peserta didik pada perancangan proyek, pengerjaan produk dan penampilan produk yang dihasilkan. Selanjutnya menurut Kosasih (Kosasih, 2014) Project Based Learning adalah model pembelajaran yang tujuannya untuk membuat kegiatan atau proyek tertentu. Sedangkan menurut Fitriana, dkk (Fitrina et al., 2016) Project Based Learning (PjBL) adalah penugasan kompleks yang berdasarkan pada pertanyaan-pertanyaan atau permasalahan tertentu, dengan keterlibatan peserta didik dalam merancang, menyelesaikan masalah, mengambil keputusan atau aktivitas eksplorasi, memberikan keleluasaan bagi peserta didik untuk dapat bekerja bebas pada kurun waktu yang ditentukan, dan akhirnya akan menghasilkan karya yang nyata atau berupa presentasi produk.

Dari berbagai pendapat beberapa ahli tersebut diperoleh kesimpulan bahwa Project Based Learning (PjBL) merupakan suatu model yang menitikberatkan pada aktivitas peserta didik supaya prinsip atau konsep mudah dipahami dengan melakukan eksplorasi mendalam tentang suatu permasalahan, menemukan solusi yang relevan dan akan diaplikasikan dalam kegiatan proyek, sehingga kegiatan pembelajaran yang dialami peserta didik lebih bermakna dengan cara membangun pengetahuannya sendiri. Model Project Based Learning memperbolehkan peserta didik untuk dapat bekerja sama secara 


\section{Histogram: Jurnal Pendidikan Matematika, 4 (2), 2020 - 348 Astri May Handayani ${ }^{1}$, Uki Suhendar², Senja Putri Merona ${ }^{3}$}

berkelompok sehingga menhasilkan karyanya yang diperoleh dari masalah kehidupan sehari-hari. Dengan penerapan model PjBL, diharapkan konsep yang dibangun peserta didik dengan pengetahuannya sendiri dapat lebih mudah dipahami sehingga kemampuan berpikir kreatif dapat ditingkatkan melalui pembuatan proyek.

Menurut Buck Institute for Education (Hosnan, 2014) beberapa karakteristik dari model Project Based Learning antara lain: (1) Melibatkan peserta didik dalam pengambilan keputusan pada kerangka kerja yang ditentukan; (2) Memecahkan suatu permasalahan atau tantangan yang belum pasti memiliki jawaban; (3) Menemukan solusi dengan cara merancang proses yang akan digunakan peserta didik; (4) Memberikan dorongan pada peserta didik dalam memecahkan masalah dengan cara berpikir kritis dengan mengkolaborasikannya serta mengkomunikasikannya dengan berbagai macam cara; (5) Mengumpulkan informasi yang telah dicari dan dikelola peserta didik akan dipertanggungjawabkan; (6) Mengundang pakar-pakar atau ahli dalam bidang proyek sebagai guru yang akan memberikan pencerahan peserta didik pada sesi-sesi tertentu; (7) Selama proyek dikerjakan guru terus-menerus melakukan evaluasi; (8) Kegiatan refleksi dilakukan untuk melihat proses maupun hasil yang telah dilakukan peserta didik; (9) Guru mengevaluasi kualitas produk dari akhir proyek yang dipresentasikan di depan kelas; (10) Mengkondisikan suasana dalam kelas dengan toleransi secara penuh terhadap perubahan dan kesalahan, serta adanya dorongan umpan balik dan revisi.

Dari 10 karakteristik PjBL tersebut, sangat dimungkinkan kemampuan berpikir kreatif matematis dapat ditingkatkan. Dikarenakan model PjBL dapat menyelesaikan suatu masalah pada dunia nyata dengan melatih peserta didik untuk berpikir dengan lancar, luwes, orisinil dan berpikir secara terperinci.

Menurut (Sani, 2015) tahapan dari model PjBL yang dapat dilakukan antara lain: (1) Menyajikan Permasalahan: Guru mengajukan permasalahan dalam bentuk pertanyaan yang dapat memotivasi belajar peserta didik. Permasalahan tersebut adalah masalah kehidupan sehari-hari dan membutuhkan penyelidikan mendalam; (2) Membuat Perencanaan: Guru memerlukan perencanaan standar kompetensi yang dianalisis saat membahas suatu masalah. Konsep penting dalam kurikulum sebaiknya terdapat pada kompetensi yang dikaji. Peserta didik harus terlibat dalam bertanya, pembuatan rencana, dan kelengkapan rencana kegiatan proyek. Pada tahap ini guru dan peserta didik akan terlibat dalam mencurahkan pendapat yang akan mendukung proses bertanya dan mencari solusi untuk menyelesaikan masalah; (3) Menyusun Penjadwalan: Guru dan peserta didik harus menulis jadwal pelaksanaan proyek yang telah disepakati. Jadwal pelaksanaan 


\section{Histogram: Jurnal Pendidikan Matematika, 4 (2), 2020 - 349 Astri May Handayani ${ }^{1}$, Uki Suhendar², Senja Putri Merona ${ }^{3}$}

proyek tersebut memuat tahapan-tahapan pengerjaan proyek dan acuan capaian tiap pertemuan di kelas; (4) Monitor Pembuatan Proyek: Guru harus memonitor dan memfasilitasi proses pelaksanaan pekerjaan peserta didik sedikitnya dua tahapan yang mereka lakukan (checkpoint). Jika diperlukan, guru dapat memberikan kesempatan untuk peserta didik praktik di laboratorium sekolah atau fasilitas lainnya. Guru juga perlu membimbing proses pelaksanaan proyek, serta melakukan instruksi dan menyediakan rubrik pada setiap konten pembelajaran; (5) Melalukan Penilaian: Guru menilai proyek secara otentik dengan menggunakan beberapa variasi jenis penilaian yang diselesaikan dalam waktu tertentu. Untuk mengetahui pemahaman peserta didik, kemampuan dalam mengimplementasikan, kemampuan dalam menyelidiki, dan kemampuan dalam menerapkan suatu keterampilan dalam pembuatan proyek atau karya yang diperlakukan penilaian ini; (6) Mengevaluasi: Mengevaluasi diartikan sebagai pemberian peluang untuk peserta didik dalam merefleksi suatu pembelajaran yang dilakukan secara individu ataupun berkelompok. Peserta didik saling berbagi pengalaman dan perasaan, berdiskusi apa yang perlu diubah dan tidak perlu diubah, serta berbagai ide mengarah pada pertanyaan dan pencarian solusi baru.

\section{Lembar Kerja Know Want Learn}

Ogle (Mihardi, dkk., 2013) mengungkapkan bahwa Know Want learn (KWL) merupakan strategi yang menyediakan struktur kegiatan dan membangun pengetahuan yang dimilikinya, menetapkan tujuan untuk meringkas apa yang dipelajari. Strategi ini berguna untuk refleksi, evaluasi pengalaman belajar, dan digunakan untuk menilai.

Menurut Harsono, A.S. R., dkk (Harsono, dkk., 2012) strategi KWL adalah strategi yang digunakan untuk membaca dengan beberapa tahapan, apa yang sudah diketahui (K), apa yang ingin dipelajari (W), dan apa yang telah dipelajari (L). Pengembangan dari strategi ini dapat membantu guru dalam menumbuhkan latar belakang pengetahuan dan minat peserta didik pada tema tertentu. Selain itu, strategi ini dapat dilakukan dengan tiga langkah, yaitu menemukan latar belakang pengetahuan peserta didik dengan cara mencurahkan pendapatnya, menetapkan beberapa hal yang diketahui peserta didik dengan cara menulis pertanyaan yang ada kaitannya dengan sesuatu yang akan dipelajari, dan yang terakhir menetapkan berbagai hal yang telah dipelajari peserta didik dengan cara menanggapi pertanyaan yang telah dirumuskan sebelumnya.

Menurut Mihardi (Mihardi, dkk., 2013) langkah-langkah KWL antara lain: (1) Memilih sebuah topik dan menggambar tabel dengan tiga kolom dan dua baris, baris 


\section{Histogram: Jurnal Pendidikan Matematika, 4 (2), 2020 - 350}

Astri May Handayani', Uki Suhendar², Senja Putri Merona ${ }^{3}$

pertama berisi judul dan baris kedua untuk mencatat. Kolom pertama diberi judul K:"What I Know", kolom kedua diberi judul W:"What I Want To Know", dan kolom ketiga L:"What I Learned"; (2) Peserta didik secara berkelompok mendiskusikan apa yang sudah diketahui pada topik yang dipilih. Kemudian ide yang diperoleh dituliskan pada kolom K “What I Know”; (3) Peserta didik diminta menyusun daftar apa yang ingin dipelajari atau pertanyaan yang akan mereka dijawab pada kolom W "What I Want To Know”. Kemudian peserta didik mencari jawaban secara aktif atas pertanyaan mereka sendiri untuk memverifikasi pengetahuan mereka; (4) Selanjutnya peserta didik mendiskusikan dan mencatat apa yang sudah mereka pelajari pada kolom L, dengan memperhatikan pertanyaan W. Kemudian peserta didik diberikan peluang untuk menggunakan strategi ini secara berkelompok dan secara mandiri. Kolom L dapat juga berfungsi sebagai catatan untuk ditinjau atau direvisi.

4. Model PjBL dengan Lembar Kerja KWL

Model PjBL dengan lembar kerja KWL merupakan model PjBL yang dikembangkan dengan cara menggabungkan lembar kerja KWL dalam penerapan model $\mathrm{PjBL}$ dalam proses pembelajaram. Tahapan dalam model PjBL disesuaikan dengan aktivitas peserta didik untuk menggunakan lembar kerja KWL. Dengan kombinasi tersebut pembelajaran model PjBL akan lebih efektif dan efisien. Selain itu, tujuan pembelajaran dari kombinasi tersebut akan tercapau dan sesuai dengan yang direncanakan yaitu penggunaan waktu menjadi lebih efisien dan sistematis. Oleh karena itu, lembar kerja KWL dapat membuat peserta didik tetap fokus pada susunan rencana proyek dan akan menghasilkan suatu produk atau karya sebagai hasil dari proses berpikir kreatif.

Menurut Mihardi, dkk (Mihardi, dkk., 2013) penggunan lembar kerja KWL dapat dimasukkan dalam langkah pertama hingga langkah keenam pada model PjBL. Proses pengendaliannya dikombinasikan dengan ketentuan KWL. Istilah KWL disesuaikan dengan langkah-langkah model PjBL berdasarkan tujuan masing-masing istilah lembar kerja KWL. Penempatan lembar kerja KWL dengan model PjBL secara bertahap sebagai berikut:

Tabel 1. Tahapan PjBL dengan Lembar Kerja KWL

\begin{tabular}{cll}
\hline No & \multicolumn{1}{c}{ Tahapan PjBL } & \multicolumn{1}{c}{ Aspek KWL } \\
\hline 1. & Menyajikan permasalahan & $\mathrm{K}($ Know $)$ \\
2. & Membuat perencanaan & "Apa yang kalian ketahui?" \\
3. & Menyusun penjadwalan & \\
4. & Monitor pembuatan proyek & $\mathrm{W}$ (Want)
\end{tabular}




\section{Histogram: Jurnal Pendidikan Matematika, 4 (2), 2020 - 351 \\ Astri May Handayani', Uki Suhendar², Senja Putri Merona ${ }^{3}$}

\begin{tabular}{cll}
\hline No & \multicolumn{1}{c}{ Tahapan PjBL } & \multicolumn{1}{c}{ Aspek KWL } \\
\hline & & "Apa yang kalian butuhkan atau \\
& yang ingin kalian ketahui?" \\
5. & Melakukan penilaian & L (Learn) \\
6. & Mengevaluasi & "Apa yang telah kalian pelajari?" \\
\hline
\end{tabular}

(Sumber: Mihardi, dkk., Tahun: 2013)

Penerapan dari tahapan PjBL dengan lembar kerja KWL dalam pembelajaran pada langkah pertama adalah menyajikan permasalahan yang diberikan guru, perencanaan kegiatan pembuatan proyek, dan jadwal pelaksanaan proyek peserta didik pada ketiga tahapan ini dapat menggunakan aspek K (Know) "Apa yang kalian ketahui?" peserta didik dapat menuliskan apa yang mereka ketahui pada kolom $\mathrm{K}$ untuk mengidentifikasi permasalahan yang diberikan guru, selanjutnya dari identifikasi tersebut peserta didik dapat membuat perencanaan pembuatan proyek untuk mencari solusi dari permasalahan yang diberikann, dan menyusun jadwal pelaksanaan proyek atau tahapantahapan dari pengerjaan proyek.

Langkah selanjutnya adalah memonitor pembuatan proyek. Pada tahapan ini digunakan aspek W (What) “Apa yang kalian butuhkan atau yang ingin kalian ketahui?”, peserta didik dapat membuat daftar apa saja yang ingin dipelaji atau pertanyaan yang akan mereka jawab pada kolom W. guru juga perlu membimbing proses pelaksanaan kegiatan pembuatan proyek.

Langkah terakhir adalah melakukan penilaian dan evaluasi. Pada tahapan ini digunakan aspek L (Learn) “Apa yang telah kalian pelajari?”, peserta didik akan mencatat hasil apa yang telah dipelajari pada kolom L. Selanjutnya hasil proyek peserta didik akan dinilai oleh guru dengan menggunakan beberapa variasi jenis penilaian. Kemudian peserta didik diberikan kesempatan untuk merefleksi pembelajaran yang dilakukan, peserta didik saling berbagi pengalaman, berdiskusi, dan berbagi ide yang mengarah pada pertanyaan dan pencarian solusi baru.

Dari langkah-langkah model PjBL dengan lembar kerja KWL tersebut, kemampuan berpikir kreatif matematis peserta didik semakin meningkat. Dikarenakan model PjBL yang digabungkan dengan lembar kerja KWL dapat menjadikan peserta didik lebih paham akan materi yang sudah dipelajari melalui proses-proses penyelesaian masalah matematika dengan pembuatan proyek sehingga dihasilkan suatu produk dan kreativitas peserta didik akan meningkat. Selain itu, peningkatan kreativitas peserta didik diukur menggunakan indikator kemampuan berpikir kreatif, diantaranya berpikir dengan lancar, luwes, orisinil dan berpikir secara terperinci. Selain itu, penggunaan lembar kerja 


\section{Histogram: Jurnal Pendidikan Matematika, 4 (2), 2020 - 352 Astri May Handayani', Uki Suhendar², Senja Putri Merona ${ }^{3}$}

KWL dapat mengontrol proses pembelajaran menjadi lebih efisien dan sistematis, serta mampu mengatasi masalah penggunaan waktu pada model PjBL supaya lebih fokus dalam kegiatan pembelajaran peserta didik.

\section{KESIMPULAN DAN SARAN}

\section{A. Kesimpulan}

Kemampuan berpikir kreatif dapat ditingkatkan atau dipengaruhi dengan membiasakan peserta didik supaya dapat menciptakan gagasan atau ide baru untuk mencari solusi dari suatu permasalahan matematika sehingga menjadikan peserta didik lebih paham dengan materi yang diberikan. Oleh karena itu, kegiatan pembelajaran seperti ini merupakan langkah yang tepat dalam melatih peserta didik supaya dapat menghasilkan suatu karya dan kemampuan berpikir kreatif peserta didik semakin meningkat. Model PjBL merupakan model yang dapat mendukung pembelajaran matematika di sekolah. Dengan dukungan alat dan media dalam model ini, harapannya peserta didik mampu untuk berpikir kreatif dalam mengubah cara belajar mengajar yang pasif menjadi lebih aktif sehingga memungkinkan hasil belajarnya semakin meningkat. Berdasarkan karakteristik PjBL, sangat dimungkinkan kemampuan berpikir kreatif matematis peserta didik dapat ditingkatkan. Dikarenakan model PjBL dapat menyelesaikan suatu masalah dalam kehidupan nyata dengan melatih peserta didik untuk berpikir dengan lancar, luwes, orisinil dan berpikir secara terperinci. Dengan tahapantahapan model PjBL yang dikombinasikan dengan lembar kerja KWL, kemampuan berpikir kreatif matematis peserta didik semakin meningkat. Dikarenakan model PjBL yang digabungkan dengan lembar kerja KWL dapat menjadikan peserta didik lebih paham dengan materi yang sudah dipelajari melalui proses-proses penyelesaian masalah matematika dengan pembuatan proyek sehingga dihasilkan suatu produk dan kreativitas peserta didik akan meningkat. Selain itu, peningkatan kreativitas peserta didik diukur menggunakan indikator kemampuan berpikir kreatif, diantaranya berpikir dengan lancar, luwes, orisinil dan berpikir secara terperinci. Selain itu, penggunaan lembar kerja KWL dapat mengontrol proses pembelajaran menjadi lebih efisien dan sistematis, serta dapat mengatasi masalah penggunaan waktu pada model $\mathrm{PjBL}$ supaya lebih fokus dalam kegiatan pembelajaran peserta didik.

\section{B. Saran}

Untuk tindak lanjut pelaksanaan penelitian ini disarankan dengan melakukan penelitian dengan metode penelitian yang lain, yang meneliti pengaruh model $\mathrm{PjBL}$ 


\section{Histogram: Jurnal Pendidikan Matematika, 4 (2), 2020 - 353}

Astri May Handayani', Uki Suhendar², Senja Putri Merona ${ }^{3}$

dengan lembar kerja KWL terhadap kemampuan berpikir kreatif matematis secara praktis. Selain itu, terdapat faktor lain yang dapat dipengaruhi dengan kombinasi model PjBL dengan lembar kerja KWL, maka dapat diteliti.

\section{DAFTAR PUSTAKA}

Aminullah. (2017). Kajian Penggunaan Metode Pembelajaran Berbasis Proyek (Project Based Learning) Dalam Meningkatkan Kemampuan Berpikir Kreatif Matematis. Prosiding Seminar Nasional Pendidik Dan Pengembang Pendidikan Indonesia.

Fitriarosah, N. (2016). Pengembangan Instrumen Berpikir Kreatif Matematis Untuk Siswa SMP. Prosiding Seminar Nasional Pendidikan Matematika, 1, 243-250.

Fitrina, T., Ikhsan, M., \& Munzir, S. (2016). Peningkatan Kemampuan Berpikir Kreatif dan Komunikasi Matematis Siswa SMA melalui Model Pembelajaran Project Based Learning Berbasis Debat. Jurnal Didaktik Matematika, 3(1), 87-95.

Gülbahar, Y., \& Tinmaz, H. (2006). Implementing project-based learning and E-portfolio assessment in an undergraduate course. Journal of Research on Technology in Education. https://doi.org/10.1080/15391523.2006.10782462

Harsono, A. S. R., Fuady, A., \& Saddhono, K. (2012). Pengaruh Strategi Know Want To Learn (KWL) Dan Minat Membaca Terhadap Kemampuan Membaca Intensif Siswa SMP Negeri Di Temanggung. Jurnal Penelitian Bahasa, Sastra Indonesia, Dan Pengajarannya, 1(1), 142-152.

Hosnan, M. (2014). Pendekatan Saintifik dan Kontekstual dalam Pembelajaran Abad 21 Kunci Sukses Implementasi Kurikulum 2013. In Bogor: Ghalia Indonesia.

Kosasih, E. (2014). Strategi belajar dan pembelajaran Implementasi Kurikulum 2013. In Bandung: Yrama Widya.

Maula, M. M., Prihatin, J., \& Fikri, K. (2014). Pengaruh Model PjBL ( Project-Based Learning ) terhadap Kemampuan Berpikir Kreatif dan Hasil Belajar Siswa pada Materi Pengelolaan Lingkungan. Jurnal Kajian Pendidikan Dan Hasil Penelitian.

Mihardi, S., Harahap, M. B., \& Sani, R. A. (2013). The Effect of Project Based Learning Model with KWL Worksheet on Student Creative Thinking Process in Physics Problems. Journal of Education and Practice.

Moma, L. (2015). Pengembangan Instrumen Kemampuan Berpikir Kreatif Matematis Untuk Siswa Smp. Delta-Pi: Jurnal Matematika Dan Pendidikan Matematika.

Noviyana, H. (2017). Pengaruh Model Project Based Learning Terhadap Kemampuan Berpikir Kreatif Matematika Siswa. JURNAL E-DuMath. 
Histogram: Jurnal Pendidikan Matematika, 4 (2), 2020 - 354

Astri May Handayani ${ }^{1}$, Uki Suhendar², Senja Putri Merona ${ }^{3}$

https://doi.org/10.26638/je.455.2064

Rina Putri Utami, R. M. P. U. F. (2015). Pengaruh Model Pembelajaran Project Based

Learning Berbantu Instagram Terhadap Kemampuan Berpikir Kreatif Siswa Kelas X SMA Negeri 8 Surakarta. Bio-Pedagogi.

Sani, R. A. (2015). Pembelajaran Saintifik Untuk Implementasi Kurikulum 2013. Bumi Aksara.

Sulistiarmi, W. (2016). Analisis Kemampuan Berpikir Kreatif Siswa Kelas XI-IPA pada Mata Pelajaran Fisika SMA Negeri Se-kota Pati. Universitas Negeri Semarang.

Widiana, Z. R. W., \& Hernadi, J. (2018). Analisis Penerapan Teknik Brainstorming Terhadap Kemampuan Berpikir Kreatif Dan Berpikir Kritis Siswa Pada Pembelajaran Matematika. EDUPEDIA. https://doi.org/10.24269/ed.v2i2.182

Yam, S., \& Rossini, P. (2010). Implementing A Project-Based Learning Approach In An Introductory Property Course. PRRES. 